Mamba'ul 'Ulum, Vol. 14, No. 2 Oktober 2018: 1-13

\title{
FENOMENA BERBAGAI METODE CEPAT MEMBACA AL-QUR'AN (Praksis Dakwah Islam di Indonesia)
}

\author{
Edy Muslimin \\ Institut Islam Mamba’ul ‘Ulum Surakarta
}

\begin{abstract}
Abstrak
Metode cepat membaca Al Qur'an begitu cepat berkembang yang semula Metode iqro' menjadi satu-satunya solusi mengatasi problem umat yaitu buta hurup Al Qur'an, Setelah era iqro' kemudian semakin banyak bermunculan ide-ide kreatif dalam menemukan berbagai metode membaca Al Qur'an, karena metode memiliki peranan sangat penting dalam upaya pencapaian tujuan pembelajaran. Dalam menyusun karya ilmiah ini penulis memilih studi pustaka yang penulis kaji dari berbagai sumber buku teks dan karya penelitian. Hasil telaah penulis bahwa Al-Qur'an merupakan kitab suci yang diturunkan paling akhir sebagai penyempurna kitab - kitab sebelumnya diperuntukkan bagi seluruh umat manusia dan sebagai bahan dakwah yang utama. Dakwah memiliki tujuan menarik orang atau memberikan pengertian kepada orang lain tentang sesuatu hal. Praksis dakwah Islam merupakan upaya pengembangan masyarakat yang bermakna sebagai usaha untuk membangun masyarakat dari segenap aspeknya.
\end{abstract}

Kata Kunci : Praksis Dakwah, Al Qur'an, Metode Cepat

\section{Pendahuluan}

Al-Qur'an merupakan kitab suci yang diturunkan paling akhir sebagai penyempurna kitab - kitab sebelumnya diperuntukkan bagi seluruh umat manusia. Secara umum umat Islam menginginkan dapat membaca Al Qur'an sebagai pintu awal memasuki pemahaman terhadap ajaran - ajaran Islam. Kunci untuk memahami ayat Al Qur'an adalah terlebih dahulu mampu membaca hurup Al-Qur'an secara benar dan tepat baik dari sisi cara melafalkan hurup sesuai dengan mahraj-nya, hukum pada setiap bacaannya dan keindahan suara dalam melantunkan bacaan - bacaan tersebut. Abudin Nata mendefinisikan Al-Qur'an adalah kitab suci yang berisi firman Allah, diturunkan secara bertahap melalui perantara malaikat Jibril yang diwahyukan kepada Nabi Muhammad SAW yang susunannya dimulai dari Al Fatihah dan diakhiri dengan Surat An Naas, yang membacanya dinilai ibadah dan sebagai hujjah (bukti) yang kuat atas kerasulan Nabi Muhammad SAW. ${ }^{1}$

Al Qur'an merupakan kalamullah yang di dalamnya berisi tentang berbagai macam ilmu pengetahuan dan syariat yang harus dibaca, dipahami dan yang paling penting diamalkan. Oleh karena itu diberbagai lembaga pendidikan Islam baik pendidikan formal maupun

\footnotetext{
${ }^{1}$ Abudin Nata, 1998, Metodologi Studi Islam, Yogyakarta, Raja Grafindo Perkasa, h 54
} 
nonformal Al Qur'an merupakan bahan kurikulum utama. Pembahasan Al Qur'an terdiri dari membaca, menterjemahkan, menafsirkan, memahamkan dan tertinggi adalah mengamalkan. Dalam memahami dan mengamalkan ajaran yang bersumber pada Al Qur'an sering sekali menjadi masalah tersendiri disebabkan karena kemampuan umat dalam membaca hurup-hurup arab yang ada dalam Al Qur'an. Berbagai upaya telah ditempuh oleh para pakar untuk menemukan cara bagaimana supaya lebih mudah dalam memahami cara membaca $\mathrm{Al}$ Qur'an dengan baik dan benar.

Pada era tahun 90 -an terjadi sebuah terobosan masif dengan hadirnya sebuah metode membaca Al Qur'an yaitu IQRO'. Metode iqro' seolah menjadi satu-satunya solusi mengatasi problem umat yaitu buta hurup Al Qur'an. Setelah era iqro' kemudian semakin banyak bermunculan ide-ide kreatif dalam menemukan berbagai metode membaca Al Qur'an yang diklaim lebih memudahkan dan cepat dalam memahami cara membaca Al Qur'an. Keinginan dapat membaca Al Qur'an tidak saja datang dari anak-anak usia belajar namun juga mulai datang daya tarik dari para orang dewasa atau generasi tua yang merasa sudah terlambat dan tidak akan mampu lagi membaca Al Qur'an. Hadirnya beberapa metode membaca Al Qur'an menjadi daya tarik tersendiri sehingga belakangan peminat pembelajar Al Qur'an semakin bertambah, oleh karena itu kebutuhan sebuah metode membaca Al Qur'an yang dapat dimanfaatkan untuk diaplikasikan dalam berbagai usia menjadi sebuah keniscayaan.

Dengan metode - metode tersebut diharapkan kemampuan membaca Al Qur'an dapat meningkat dari sisi cara melafalkan hurup demi hurup, hukum tajwid dan keindahan membacanya sehingga secara umum masyarakat dapat membaca secara tartil. Dalam hal ini sebagaimana terdapat dalam firman Allah sebagai berikut :

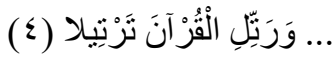

Artinya :

dan bacalah Al Quran itu dengan perlahan-lahan. ${ }^{2}$

Ditegaskan juga dalam sebuah sabda Rasulullah SAW sebagai berikut:

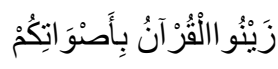

Artinya : Hiasilah Al-Qur'an dengan suara kalian (HR. Ahmad \& Abu Daud)

Dari uraian diatas dapat dipahami bahwa metode pembelajaran Al Qur'an bertujuan untuk mempermudah umat Islam dalam membaca Al Qur'an, supaya mampu membacanya

\footnotetext{
${ }^{2} \mathrm{Al}$ Qur'an dan terjemahnya, Qs. Al Muzzamil ayat 4, Jakarta, PT Insan Media Pustaka, h 574
} 
dengan benar sesuai kaidah agar umat terhindar dari kesalahan memaknai isi Al Qur'an yang merupakan pedoman hidup. Dari paparan ini kemudian memunculkan beberapa pertanyaan yaitu pertama, apakah berbagai metode cepat membaca Al Qur'an dapat mempercepat kemampuan membaca Al-Qur'an, kedua, Bagaimana implementasi penggunaan berbagai metode dalam membaca Al-Qur'an, ketiga, bagaimana praksis dakwah Islam di Indonesia melalui metode cepat membaca Al Qur'an?

\section{Metode Membaca Al Qur'an dan Praksis Dakwah di Indonesia}

\section{Definisi}

Metode dalam bahasa Yunani diartikan sebagai "Methodos" yaitu cara atau jalan. ${ }^{3}$ Sedang menurut pendapat Basyirudin Usman metode adalah cara menyajikan materi secara baik sehingga hasilnya efektif dan efisien. ${ }^{4}$ Sedang membaca adalah kegiatan meresepsi, menganalisis dan menginterpretasi yang dilakukan oleh pembaca untuk memperoleh pesan yang hendak disampaikan oleh penulis dalam media tulisan. Kegiatan membaca meliputi membaca nyaring dan membaca dalam hati. Membaca nyaring merupakan kegiatan membaca yang dilakukan dengan cara membaca keras - keras di depan umum, membaca dalam hati adalah kegiatan membaca dengan seksama yang dilakukan untuk mengerti dan memahami maksud atau tujuan penulis dalam media tertulis. ${ }^{5}$

Al Qur'an adalah kalam Tuhan yang diturunkan kepada Nabi Muhammad SAW dalam waktu kurang lebih dua puluh tiga tahun yang tertuang dalam mushaf (lembaran) yang selanjutnya sebagai pedoman umat manusia sepanjang masa. Beberapa nama Al Qur'an yang masing - masing menunjukkan fungsinya yaitu Pertama, Al Qur'an yang artinya bacaan yang harus dibaca. Kedua, Al Furqan berarti pembeda yang baik dan yang buruk yang benar dan yang salah. Ketiga, Al Kitab yang memiliki arti tulisan atau yang ditulis. Keempat, Al Dzikr yang didefinisikan peringatan dari Allah SWT. Kelima, At Tibyan yang merupakan penjelasan dari Allah atas segala sesuatu dan keenam, Asy Syifa' diartikan obat penawar. ${ }^{6}$

Praksis dalam kamus Besar Bahasa Indonesia diartikan bidang kehidupan dan kegiatan praktis manusia. ${ }^{7}$ Kata praksis sering digunakan sebagai alternatif dari kata praktik atau aksi. Praksis secara umum menunjuk pada sebuah cara berfikir, sedang secara khusus kata praksis menunjuk pada sebuah metode atau model. Cara kerja model praksis mengacu pada aksi atas

\footnotetext{
${ }^{3}$ Dzikron Abdullah, 1985, Metodologi Dakwah, Semarang, Fakultas Dawah IAIN Walisongo, h 3-4

${ }^{4}$ Basyirudin Usman, 2002, Metodologi Pembelajaran Agama Islam, Jakarta, Ciputat Pers, h 31

${ }^{5}$ https://id.m.wikipedia.org, akses pada tanggal 20 Agustus 2018

${ }^{6}$ Amin Syukur, 1998, Metodologi Studi Islam, Semarang, Percetakan Gunungjati, h: 5

${ }^{7}$ W.J.S. Poerwadarminto, 1995. Kamus Umum Bahasa Indonesia, Jakarta, Balai Pustaka, h:
} 
refleksi dan refleksi terhadap aksi, membantu pengenalan akan makna dan dapat memberikan sumbangsih bagi perubahan sosial. ${ }^{8}$

Dakwah menurut bahasa sebagai bentuk masdar dari kata kerja da-a, yad-uu yang memiliki arti memanggil, mendorong dan mengajak. ${ }^{9}$ Toha Yahya Omar mendefinisikan dakwah dengan makna yang lain yaitu penerangan, pendidikan, pengajaran, indoktrinasi dan propaganda. Penerangan memiliki tujuan menarik orang atau memberikan pengertian kepada orang lain tentang sesuatu hal. Penyiaran merupakan salah satu cara dari pelaksanaannya. Pendidikan dan pengajaran keduanya menjadi bagian dan cara atau alat dalam berdakwah melalui pembiasaan diri. Mengindoktrinasi berarti memberikan ajaran - ajaran pokok yang menjadi pedoman bagi orang yang menerima doktrin untuk bertindak. Propaganda dalam bahasa Yunani "propagare" diartikan menyebarkan atau meluaskan. ${ }^{10}$

Joko Tri Haryanto menyebut Istilah lain dari dakwah yaitu :

a. Tabligh berasal dari kata "ballagha" yang berarti menyampaikan sesuatu atau menyampaikan sesuatu ajaran, pendapat atau petunjuk. Dalam hal ini ialah menyampaikan sesuatu kepada manusia semua amanat yang diperintahkan Allah untuk menyampaikannya;

b. An-Nashihat atau nasehat yang berasal dari "nashaha" yang berarti menjahit (pakaian), membersihkan sesuatu (dari campuran). Istilah ini berkembang menjadi petunjuk yang baik dan usaha untuk memperbaiki tingkah laku seseorang atau sekelompok orang;

c. Ad-Diayah, yang berasal dari kata da'a, sama dengan dakwah tetapi lebih menekankan pada usaha menarik perhatian, simpati (perasaan senang) seseorang atau sekelompok orang terhadap sesuatu sikap, tindakan atau fikiran dengan menggunakan bujukan, pujian dan sebagainya. Atau mirip artinya dengan propaganda dan sejenisnya.

Menurut Amrulloh sebagaimana dikutip oleh Joko Tri Haryanto persepsi tentang pengertian dakwah ini dibedakan dalam dua pola pengertian. Pertama adalah dakwah diberi pengertian tabligh/penyiaran/penerangan agama. Kedua, dakwah diberi pengertian semua usaha untuk merealisir ajaran Islam dalam semua segi kehidupan manusia. Pada pengertian pertama, terlalu sempit sehingga tidak mampu menghubungkan antara simbol dan realitas

\footnotetext{
${ }^{8}$ https://id.m.wikipedia.org, akses pada tanggal 20 Agustus 2018

${ }^{9}$ Dzikron Abdullah, 1985, Metodologi Dakwah, Semarang, Fakultas Dawah IAIN Walisongo, h: 7

${ }^{10}$ Toha Yahya Omar, 1992, Ilmu Dakwah, Jakarta, Penerbit Widjaya, h: 1-2
} 
. Oleh karena dakwah lebih identik dengan kegiatan pidato di mimbar - mimbar atau budaya dakwah oral (verbal) yang mengakibatkan Islam tidak mampu memasuki lebih dalam dari sistem kepribadian dan sosial. Akibatya dakwah sering tidak mampu menjawab secara konkrit masalah yang dihadapi umat manusia. Sementera pengertian kedua pun cenderung terlalu luas sehingga perlu pembatasan - pembatasan agar dapat dibedakan dengan kegiatan yang lain. ${ }^{11}$

\section{Berbagai Metode Membaca Al Qur'an}

Dalam proses pembelajaran metode memiliki peranan sangat penting dalam upaya pencapaian tujuan pembelajaran. Husni Syekh Utsman (dalam HR. Taufiqurrohman) menjelaskan ada tiga asas yang harus diperhatikan seorang pendidik dalam mengajar berbagai pelajaran termasuk didalamnya pembelajaran membaca Al Qur'an yaitu : Pertama, pembelajaran dimulai dari hal-hal yang telah dikenal peserta didik hingga hal-hal tidak diketahui. Kedua, dimulai dari yang paling mudah hingga paling sulit. Ketiga, dimulai dari yang sederhana dan ringkas hingga hal-hal terperinci. ${ }^{12}$

Metode pembelajaran Al Qur'an banyak dikembangkan di Indonesia dengan berbagai model berdasarkan ciri khas dan keunggulan masing - masing metode yang ditawarkan. Beberapa metode tampil dengan karakteristik yang berbeda - beda, perbedaan karakteristik ini disinyalir menonjolkan fokus yang hendak dicapai setelah mempelajarinya. Achmad Zainuddin Fannani dalam penelitiannya mengurai tentang karakteristik berbagai metode membaca $\mathrm{Al}$ Qur'an antara lain :

Pertama, metode Al Baghdadiyah menyebutnya sebagai metode "eja" yang materinya diurutkan dari yang konkrit ke abstrak, dari yang mudah ke sukar, dari yang umum sifatnya ke materi yang terinci (khusus). Qoidah metode baghdadiyah memerlukan tujuh belas langkah dan memerlukan waktu yang cukup lama untuk mampu membaca Al Qur'an.

Kedua, metode Iqro' yang disusun oleh As'ad Humam dari Kota Gede Yogyakarta yang kemudian dikembangkan oleh Angkatan Muda Masjid dan Musholla dengan membuka TK Al Qur'an dan Taman Pendidikan Al Qur'an. metode Iqro' semakin berkembang di Indonesia dan sebagai program utama perjuangan. Metode ini terdiri 6 jilid yang memiliki sepuluh sifat yaitu : bacaan langsung, CBSA, privat, modul, asistensi, praktis, disusun lengkap dan sempurna, variatif, komunikatif dan fleksibel. Bentuk pengajaran meliputi : TK Al Qur'an, TPA

\footnotetext{
${ }^{11}$ Joko Tri Haryanto, 2014, Perkembangan Dakwah Sufistik Persepektif Tasawuf Kontemporer, Jurnal Addin, Volume 8, Nomor 2, Agustus 2014, h: 271-273

${ }^{12} \mathrm{HR}$. Taufiqurrohman, 2005, Metode Jibril Metode PIQ-Singosari Bimbingan KHM Bashori Alwi, Malang, IKAPIQ, h: 41
} 
, pengajian anak-anak di Masjid, kursus baca tulis Al Qur'an, ekskul sekolah dan majlis-majlis ta'lim.

Ketiga, Metode Qiro'ati yang ditemukan oleh KH. Dachlan Salim Zarkasyi dari Semarang Jawa Tengah. Metode ini mulai dikenalkan pada awal tahun 1970-an, buku ini terdiri dari enam jilid yang sistem pengajarannya meliputi klasikal dan privat, guru menjelaskan dan memberi contoh, siswa membaca sendiri, pembelajar membaca tanpa mengeja dan ditekankan untuk membaca dengan tepat dan cepat.

Keempat, Metode Al Barqy yang ditemukan oleh dosen Muhadjir Sulthon Fakultas Adab IAIN Sunan Ampel Surabaya pada tahun 1965 dan dibukukan pada tahun 1978. Disebut metode anti lupa karena memiliki struktur yang apabila pembelajar lupa dengan huruf atau suku kata yang dipelajari maka dengan mudah dapat mengingat kembali tanpa bantuan guru.

Kelima, Metode Tilawati yang disusun oleh Drs. H. Hasan Sadzili, Drs. H. Ali Muaffa dkk. Metode ini diklaim bahwa santri atau pembelajar dapat membaca Al Qur'an dengan tartil, mampu membenarkan bacaan Al Qur'an yang salah, ketuntasan belajar individu 70\% dan secara kelompok 80\%. Prinsip yang digunakan metode ini adalah disampaikan dengan praktis, menggunakan lagu rost serta menggunakan pendekatan klasikal dan individu dengan seimbang.

Keenam, Metode Dirosa (Dirosah orang dewasa) yang secara garis besar metode pengajarannya adalah baca - tunjuk - simak - ulang yaitu pembina membacakan, peserta menunjuk tulisan, menyimak dengan seksama kemudian mengulang bacaan tersebut. Teknik ini dilakukan bukan hanya bacaan pembina tetapi juga bacaan sesama peserta, semakin banyak menyimak dan mengulang maka semakin cepat mampu membaca Al Qur’an. ${ }^{13}$

\section{Dakwah Islam di Indonesia}

\section{Sejarah Dakwah}

Menurut Toha Yahya Umar, ada yang mengatakan bahwa sejarah dakwah secara umum dimulai semenjak filosof Yunani sebelum Masehi. Tetapi sebenarnya jauh lebih tua dari itu yaitu dimulai sejak iblis mempengaruhi Nabi Adam dan Hawa dengan propagandanya yang sangat menarik dan memikat hati kedua nenek moyang kita untuk memakan buah khuldi yang dilarang itu. ${ }^{14}$ Sebagaimana disebutkan dalam Qs. Thaha ayat 120 - 121 yang terjemahannya sebagai berikut : "kemudian syaitan membisikkan pikiran jahat kepadanya, dengan berkata

\footnotetext{
${ }^{13}$ Achmad Zainuddin Fannani, 2009, Skripsi : Pemanfaatan Media Audio Visual Dalam Pembelajaran Al Qur'an di Ma'had Umar bin Khattab Surabaya, Surabaya, IAIN Sunan Ampel, h: 43-54

${ }^{14}$ Toha Yahya Omar, Ibid. h: 5
} 
: "Hai Adam, maukah saya tunjukkan kepada kamu pohon khuldi dan kerajaan yang tidak akan binasa. Maka keduanya memakan dari buah pohon itu, lalu nampaklah bagi keduanya aurat-auratnya dan mulailah keduanya menutupinya dengan daun-daun (yang ada di) surga, dan durhakalah Adam kepada Tuhan dan sesatlah ia”.

Setelah Muhammad dilantik sebagai Nabi dan Rasul maka baginda segera menjalankan dakwah Islamiyah sebagaimana yang telah diperintahkan oleh Allah SWT. Dakwah rasulullah s.a.w dibagi oleh sejarawan pada dua peringkat yaitu Mekkah dan Medinah. Dakwah di Mekkah dilakukan setelah turunnya wahyu yang pertama dari surah al 'alaq ayat $1-5$ yang menyatakan tentang pelantikan Muhammad s.a.w sebagai Nabi dan Rasul. Dakwah yang dilaksanakan oleh Rasulullah s.a.w melalui tingkatan yaitu penyediaan pelopor - pelopor dakwah diantaranya adalah Siti Khadijah, Ali bin Abi Thalib, Zaid Haritsah, Abu Bakar, Utsman bin Affan, Zubair Al Awwam, Abdurrahman Auf, Saad Abi Waqas dan lainnya sekitar 40 orang, dan tingkatan berikutnya adalah dakwah kepada keluarga dan kaum kerabat Bani Abdul Muttalib.

Dakwah di Madinah merupakan zaman meletakkan azas yang kokoh bagi pembinaan masyarakat Islam. Islam tersebar secara meluas setelah Rasulullah s.a.w hijrah ke Madinah. Oleh karena itu Rasulullah digambarkan mulai mendirikan masyarakat baru dan meletakkan asas - asas bagi masyarakat Islam yang terkenal dalam sejarah. Asas tersebut adalah :

1) Mendirikan Masjid

2) Mempersaudarakan Muhajirin dan Anshar

3) Membentuk piagam Madinah

4) Meletakkan dasar - dasar politik, ekonomi dan sosial. ${ }^{15}$

Pada awal perkembangan Islam, sejak Nabi Muhammad SAW hingga perluasan Islam sekitar tahun 970-an, dakwah Islam sangat didominasi oleh unsur - unsur perluasan kekuasaan Islam. Masa tersebut dianggap sebagai masa paling menentukan bagi Islam hingga memperoleh posisi dan kejayaannya. Agama dan penyebarannya dengan perjuangan merebut pengaruh dan kekuasaan merupakan dua hal yang sulit dipisahkan. ${ }^{16}$

\footnotetext{
${ }^{15}$ Ahmad Redzuwan Mohd. Yunus, 2001, Sejarah Dakwah, Kuala Lumpur, Taman Shamelin Perkasa, h: 1-9

${ }^{16}$ Acep Aripudin dan Mudhofir Abdullah, 2014, Perbandingan Dakwah, Bandung, PT Remaja Rosdakarya, h: 53
} 
Setelah Rosulullah meninggal, tidak berarti dakwah pun berhenti sampai di situ. Melainkan sejak saat itu tanggung jawab dakwah dilanjutkan oleh para sahabat dan pengikutnya. Munculnya istilah Khulafaur Rasyidin, merupakan penerus risalah kenabian yang juga mempunyai peranan yang signifikan dalam menyampaikan dakwah islamiyyah. Abu Bakar, Umar bin Khattab, Utsman bin Affan, dan Ali bin Abi Thalib adalah keempat sahabat terdekat nabi yang senantiasa melanjutkan risalah kenabian dalam menyampaikan kebenaran. Di tangan kepemimpinan mereka dakwah islam berkembang begitu pesat, islam bisa mencapai puncak kejayaan sampai ke luar jazirah arab. Namun, saat itu pun tantangan dakwah tak kalah beratnya, banyak hambatan yang mereka hadapi untuk menyampaikan risalah tersebut. Baik itu hambatan di dalam umat islam sendiri, maupun hambatan dari para musuh islam yang begitu gencar menentang risalah islam. Mengenai proses perjalanan sejarah dakwah, Syukriadi Sambas dalam bukunya dimensi ilmu dakwah membagi periodesasi perkembangan dakwah dalam tiga kurun waktu yang berbeda, yaitu :

1. Periode klasik(650-1250M), yaitu masa kemajuan islam I (650-1000 M) dimana terjadi dalam 3 masa pemerintahan yaitu Khulafaur Rasyidin, Bani Umayah, dan Bani Abbas. Dan masa disintegrasi (1000-1250 M)

2. Periode pertengahan (1250-1800M), yaitu masa kemunduran I (1250$1500 \mathrm{M})$ dan masa tiga kerajaan besar (1500-1800M)

3. Periode Post Modern (1800-sekarang)

\section{Sasaran Dakwah}

Sasaran dakwah Islam dibedakan menjadi dua yaitu umat dakwah dan umat ijabah. Umat dakwah adalah masyarakat non muslim. Terhadap umat dakwah bertujuan untuk mengenalkan Islam agar tertarik dengan kesadaran sendiri memeluk agama Islam. Sedang yang dimaksud umat ijabah adalah mereka yang telah memeluk Islam (kaum muslimin) yang tujuannya supaya lebih meningkatkan lagi penghayatan dan pengalaman sehingga menjadi muslim yang benar-benar Islami. ${ }^{17}$

\footnotetext{
${ }^{17}$ Abdul Munir Mulkhan, 1996, Ideologisasi Gerakan Dakwah : Episod Kehidupan M Natsir dan Azhar Basyir, Yogyakarta, Sipres, h: 208
} 


\section{Tantangan Dakwah}

Menurut Abdul Munir Mulkhan dalam rangka mengenali tantangan dakwah perlu dikaji permasalahan umat di bidang sosial budaya dan ekonomi serta politik sebagai akibat perkembangan ilmu dan teknologi pada beberapa dasawarsa mendatang. Perlu diperhatikan dalam mempelajari kecendrungan perkembangan tersebut yaitu proses industrialisasi, alih dan penerapan teknologi tinggi dan masuknya Indonesia dalam era masyarakat informasi global. Dampak dari hal ini adalah terjadinya kecendrungan pemikiran materialistik, rasionalistik, sekularistik dan spiritualistik. Tanpa mengabaikan faham yang lain, paham sekularisme merupakan ancaman serius bagi kehidupan religius umat dan bangsa. Sekularisme cendrung untuk meniadakan peran agama sekalipun ada kemungkinan bahwa agama diberi tempat atau diberi kotak yaitu berupa proses spatialisasi atau pengkotaan. Agama diberi tempat khusus pada aspek rohaniah atau spiritual saja dan tidak diberi tempat dalam aspek kehidupan lainnya. ${ }^{18}$

Tantangan dakwah yang lain menurut Toha Yahya Omar adalah karena dakwah adalah suatu aksi maka akan timbul reaksi, dan timbulnya ada yang selalu manis dan menyenangkan namun ada pula cemooh dan hujatan. Sebagaimana Rasulullah SAW dalam berdakwah tantangannya begitu besar bahkan sampai teror fisik dan psikis. Tantangan dakwah tersebut tidak hanya menimpa Nabi Muhammad SAW namun juga terhadap rasul-rasul terdahulu. ${ }^{19}$ Perihal tantangan atau rintangan dakwah ini dapat dicermati dalam Qs. Yasin ayat 30 berikut “Alangkah besarnya penyesalan terhadap hamba-hamba itu (orang-orang kafir), tiada datang seorang Rasulpun kepada mereka melainkan mereka selalu memperolok-olokkannya”.

\section{Metode Dakwah}

Al Qur'an menyiratkan pentingnya sebuah metode dalam dakwah Islamiyah. Allah SWT berfirman :

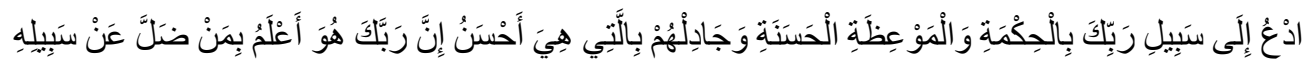

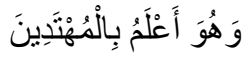

Artinya : Serulah (manusia) kepada jalan Tuhan-mu dengan hikmah dan pelajaran yang baik dan bantahlah mereka dengan cara yang baik. Sesungguhnya Tuhanmu Dialah yang lebih

\footnotetext{
${ }^{18}$ Abdul Munir Mulkhan, 1996, Ideologisasi Gerakan Dakwah : Episod Kehidupan M Natsir dan Azhar Basyir, Yogyakarta, Sipres, h: 210-211

${ }^{19}$ Toha Yahya Omar, 1992, Ilmu Dakwah, Jakarta, Penerbit Widjaya, h: 227
} 
mengetahui tentang siapa yang tersesat dari jalan-Nya dan Dialah yang lebih mengetahui orang-orang yang mendapat petunjuk. ${ }^{20}$

Dalam ayat tersebut Allah mengajar kita cara berdakwah dengan kalimat bilhikmati yang oleh Toha Yahya Omar diterjemahkan melalui pengertian berdakwah dengan bijaksana, Al-Hikmah adalah meletakkan sesuatu pada tempatnya. Selain itu harus berfikir, berusaha, menyusun dan mengatur cara - cara dengan menyesuaikan keadaan dan zaman, dengan lisan, tulisan, perbuatan atau lainnya asal saja tidak bertentangan dengan hal - hal yang dilarang Tuhan. ${ }^{21}$ Selain bilhikmati ayat diatas juga menampilkan metode mauidzah hasanah yang diartikan pelajaran yang baik atau sering dikenal dengan metode ceramah yang dalam bahasa Inggris disebut lecturing method dengan tahapan secara runtut yaitu : tahap pendahuluan, tahap penyajian materi dakwah dan penutup. Ayat tersebut juga menyebut wa jadilhum (bantahlah) dengan cara yang baik yang dimaknai dengan metode diskusi. ${ }^{22}$

\section{Materi Dakwah}

Menurut Hamzah Ya'qub materi dakwah kadang - kadang disebut ideologi dakwah yaitu ajaran Islam itu sendiri yang berpangkal pada dua pokok Al Qur'an dan Sunnah Rasulullah s.a.w. dan setiap Rasulullah s.a.w berdakwah selalu membawakan firman Allah dan menyampaikan pula penjelasannya. Segala kata - kata dan perbuatan Rasulullah s.a.w dipandang sebagai sunnah. Materi dakwah hendaknya dikemukakan dengan baik, sehingga orang yang menikmatinya benar - benar merasa terpikat dengan materi tersebut. Materi dakwah meliputi :

1) Aqidah, Tauhid dan keimanan

2) Pembentukan pribadi yang sempurna

3) Pembangunan masyarakat yang adil makmur

4) Kemakmuran dan kesejahteraan dunia akhirat. ${ }^{23}$

Dari uraian materi - materi dakwah tersebut menurut penulis hurup - hurup Al Qur'an dan cara membacanya juga merupakan materi dakwah.

\footnotetext{
${ }^{20} \mathrm{Al}$ Qur'an dan terjemahnya, Qs. An Nahl ayat 125, Jakarta, PT Insan Media Pustaka, h 281

${ }^{21}$ Toha Yahya Omar, 1992, Ilmu Dakwah, Jakarta, Penerbit Widjaya, h: 4

${ }^{22}$ Dzikron Abdullah, 1985, Metodologi Dakwah, Semarang, Fakultas Dawah IAIN Walisongo, h: 15-36

${ }^{23}$ Hamzah Ya'qub, 1992, Publisistik Islam : Teknik Dakwah dan Leadhership, Bandung, CV. Diponegoro, h: 2930
} 


\section{Praksis Dakwah Islam di Indonesia}

Praksis artinya aktivitas yang didasarkan pada pemikiran-pemikiran yang corak aksi gerakannya bersifat membebaskan, memberdayakan, dan memajukan umat dan masyarakat. ${ }^{24}$ Menurut Siti Noordjanah Djohantini pendekatan dakwah untuk memecahkan masalah sasaran dakwah sering juga disebut dakwah bil-hal yaitu metode dakwah yang lebih menekankan pada amal usaha atau karya nyata yang bisa dinikmati dan bisa mengangkat harkat, martabat, kesejahteraan hidup masyarakat. ${ }^{25}$ Dalam kontek berdakwah dengan mengajarkan cara membaca Al Qur'an teringatlah bagaimana Rasulullah s.a.w adalah rasul yang ummi dan diutus di tengah kaumnya, sebagaimana dapat dicermati dalam Al Qur'an surah Ali Imran ayat 164 yang redaksinya sebagai berikut :"sungguh Allah telah memberi karunia kepada orang-orang yang beriman ketika Allah mengutus diantara mereka seorang Rasul dari golongan mereka sendiri, yang membacakan kepada mereka ayat-ayat Allah, membersihkan (jiwa) mereka, dan mengajarkan kepada mereka Al kitab dan Al hikmah. dan Sesungguhnya sebelum (kedatangan Nabi) itu, mereka adalah benar-benar dalam kesesatan yang nyata”.

Sesungguhnya Rasul s.a.w tumbuh ditengah kaumnya yang ummi sebagai orang yang ummi juga seperti mereka. Beliau tidak dapat membaca dan tidak dapat menulis, barangkali hikmah Allah telah menetapkan bahwa yang membawa risalah kemanusiaan ini kepada manusia seluruhnya adalah satu pribadi yang tiada memasuki fitrahnya yang bersih selain pengajaran Tuhan-Nya. Pribadi itu juga akan mampu mengemban risalah kemanusiaan yang toleran, murni dan bersih dari segala noda. Ke-ummi-annya bertujuan agar dia mampu membacakan kepada mereka apa yang diajarkan Tuhan-Nya, mensucikan jiwa mereka dan memindahkan mereka dari kesesatan dan kegelapan menuju petunjuk dan cahaya. ${ }^{26}$ Menjamurnya berbagai metode membaca cepat Al Qur'an dewasa ini patut diapresiasi, sumbangsih berbagai metode tersebut turut memotivasi umat Islam dari berbagai kalangan untuk belajar Al Qur'an. Adanya minat belajar Al Qur'an tentu karna adanya peran para da'i dalam mendakwahkan ajaran Islam dalam berbagai aspek keilmuan yang ingin dipelajari oleh umat Islam diberbagai umur. Asep Muhiddin mensinyalir bahwa Al Qur'an mampu menjadi motivasi dan inspirasi perubahan sebuah peradaban manusia dari kondisi jahiliyah, kegelapgulitaan menuju kehidupan keterangbenderangan.

\footnotetext{
${ }^{24} \mathrm{http}: / / w w w . s u a r a m u h a m m a d i y a h . i d / 2017 / 03 / 14 /$ aisyiyah-istiqomah-dalam-gerakan-praksis/

${ }^{25} \mathrm{http} / / /$ www.umm.ac.id/id/muhammadiyah/1470.html

${ }^{26}$ Muhammad Ali al-Hasyimi, 2004, Kepribadian dan Dakwah Rasulullah dalam Kesaksian Al-Qur'an, Yogyakarta, Mitra Pustaka, h: 33-40
} 
Dakwah dalam makna ajakan, seruan untuk membaca, memaknai dan mengamalkan isi Al Qur'an harus secara sungguh-sungguh digarap. Fenomena ketertarikan terhadap Al Qur'an akhir-akhir ini semakin menunjukkan trend positif, hal ini dapat diamati banyak sekali tayangan televisi yang mengakomodir acara semacam lomba hafidz qur'an. Dalam hal ini tentu saja akan terkait dengan teknik-teknik membaca Al Qur'an. Dalam hal ini bahwa upaya kegiatan dakwah disamping harus dilaksanakan secara serius juga dituntut sistematis dan akademis, karena aktivitas dakwah dilihat dari sisi pelakunya adalah manusia mukallaf yang memiliki totalitas jalinan saraf yang sinergik, aktivitas atau perilakunya itu secara runtut akan muncul dari sebuah kesadaran. Oleh karena itu praksis dakwah Islam di Indonesia harus dilakukan dengan cara kerja model praksis yang mengacu pada aksi atas refleksi dan refleksi terhadap aksi, sehingga menurut Asep Muhiddin kegiatan dakwah ini melibatkan beberapa rukun atau anasir apa, siapa, kepada siapa, kapan, dimana, melalui apa, dan dengan cara bagaimana. ${ }^{27}$

Praksis dakwah Islam merupakan upaya pengembangan masyarakat. Pengembangan masyarakat Islam bermakna sebagai usaha untuk membangun masyarakat dari segenap aspeknya secara bertahap dan teratur menjurus kearah atau tujuan yang dikehendaki. ${ }^{28}$ Menurut Ilyas Ismail dan Prio Hotman bahwa dari segi tujuan dakwah dan pengembangan masyarakat memiliki keterkaitan yang satu sama lain. Dakwah dimaksudkan untuk mewujudkan kebahagiaan dan kemajuan hidup di dunia dan akhirat. Sedang dari segi metode dan pendekatan dakwah dan pengembangan masyarakat memiliki hubungan saling melengkapi. Membangun masyarakat tidak hanya pada satu aspek dengan melupakan aspek yang lain. ${ }^{29}$ Oleh karena itu praksis dakwah di Indonesia adalah dengan tidak melupakan bahwa mengajak masyarakat atau umat untuk dapat membaca Al Qur'an dengan baik adalah sebuah upaya membangun masyarakat gemar membaca.

\section{Penutup}

Dari uraian diatas dapat disimpulkan bahwa pertama, berbagai metode cepat membaca Al Qur'an merupakan upaya mempercepat kemampuan membaca Al-Qur'an. Kedua, implementasi penggunaan berbagai metode dalam membaca Al-Qur'an sangat bervariasi

\footnotetext{
${ }^{27}$ Asep Muhiddin, 2002, Dakwah dalam Perspektif Al-Qur'an, Bandung, Pustaka Setia, h: 29-32

${ }^{28}$ Tim Penyusun Kamus Besar Bahasa Indonesia, 2008, Kamus Besar Bahasa Indonesia, Jakarta, Depdiknas, h: 632

${ }^{29}$ Ilyas Ismail dan Prio Hotman, 2011, Filsafat Dakwah : Rekayasa Membangun Agama dan Peradaban Islam, Kencana Prenada Media Group, h: 226
} 
tergantung pada titik tekan yang menjadi unggulannya. Ketiga, praksis dakwah Islam di Indonesia melalui metode cepat membaca Al Qur'an adalah dengan tidak melupakan bahwa mengajak masyarakat atau umat untuk dapat membaca Al Qur'an dengan baik dan hati-hati adalah sebuah upaya membangun masyarakat gemar membaca yang dilakukan dengan cara kerja model praksis yang mengacu pada aksi atas refleksi dan refleksi terhadap aksi.

\section{DAFTAR PUSTAKA}

Abdul Munir Mulkhan, 1996, Ideologisasi Gerakan Dakwah : Episod Kehidupan M Natsir dan Azhar Basyir, Yogyakarta, Sipres

Abudin Nata, 1998, Metodologi Studi Islam, Yogyakarta, Raja Grafindo Perkasa

Achmad Zainuddin Fannani, 2009, Skripsi : Pemanfaatan Media Audio Visual Dalam Pembelajaran Al Qur'an di Ma'had Umar bin Khattab Surabaya, Surabaya, IAIN Sunan Ampel

Ahmad Redzuwan Mohd. Yunus, 2001, Sejarah Dakwah, Kuala Lumpur, Taman Shamelin Perkasa

Al Qur'an dan terjemahnya, Qs. An Nahl ayat 125, Jakarta, PT Insan Media Pustaka Amin Syukur, 1998, Metodologi Studi Islam, Semarang, Percetakan Gunungjati Asep Muhiddin, 2002, Dakwah dalam Perspektif Al-Qur'an, Bandung, Pustaka Setia Basyirudin Usman, 2002, Metodologi Pembelajaran Agama Islam, Jakarta, Ciputat Pers Dzikron Abdullah, 1985, Metodologi Dakwah, Semarang, Fakultas Dawah IAIN Walisongo Hamzah Ya'qub, 1992, Publisistik Islam : Teknik Dakwah dan Leadhership, Bandung, CV. Diponegoro

HR. Taufiqurrohman, 2005, Metode Jibril Metode PIQ-Singosari Bimbingan KHM Bashori Alwi, Malang, IKAPIQ

https://id.m.wikipedia.org http://www.umm.ac.id/id/muhammadiyah/1470.html

Ilyas Ismail dan Prio Hotman, 2011, Filsafat Dakwah : Rekayasa Membangun Agama dan Peradaban Islam, Kencana Prenada Media Group

Joko Tri Haryanto, 2014, Perkembangan Dakwah Sufistik Persepektif Tasawuf Kontemporer, Jurnal Addin, Volume 8, Nomor 2, Agustus 2014

Muhammad Ali al-Hasyimi, 2004, Kepribadian dan Dakwah Rasulullah dalam Kesaksian AlQur'an, Yogyakarta, Mitra Pustaka

Tim Penyusun Kamus Besar Bahasa Indonesia, 2008, Kamus Besar Bahasa Indonesia, Jakarta, Depdiknas, h: 632

Toha Yahya Omar, 1992, Ilmu Dakwah, Jakarta, Penerbit Widjaya

W.J.S. Poerwadarminto, 1995. Kamus Umum Bahasa Indonesia, Jakarta, Balai Pustaka 